\title{
THERMAL STABILITY OF THE ESSENTIAL OILS ISOLATED FROM TUNISIAN THYMUS CAPITATUS HOFF. ET LINK.: EFFECT ON THE CHEMICAL COMPOSITION AND THE ANTIOXIDANT AND ANTIBACTERIAL ACTIVITIES
}

\author{
S. Bounatirou ${ }^{\mathrm{a}}$, S. Smiti ${ }^{\mathrm{a}}$, M.G. Miguel ${ }^{\text {b* }}$, L. Faleiro ${ }^{\mathrm{c}}$, M.N. Rejeb ${ }^{\mathrm{d}}$, M. Neffati ${ }^{\mathrm{e}}$, \\ M.M. Costa ${ }^{f}$, A.C. Figueiredo ${ }^{f}$, J.G. Barroso ${ }^{f}$ and L.G. Pedro ${ }^{f}$ \\ ${ }^{a}$ Faculté des Sciences de Tunis, Université Tunis el Manar, Campus Universitaire, 2092 Tunis. Tunisia \\ ${ }^{\mathrm{b}}$ Faculdade de Ciências e Tecnologia, Universidade do Algarve, IBB, Centro de Biotecnologia Vegetal, \\ Campus de Gambelas, 8005-139 Faro. Portugal \\ ${ }^{c}$ Faculdade de Ciências e Tecnologia, Universidade do Algarve, IBB, Centro de Biomedecina Molecular e \\ Estrutural, Edifício 8, Campus de Gambelas, 8005-139 Faro. Portugal \\ ${ }^{d}$ Institut National de Recherche en Génie Rural, Eaux et Forêts, 2080 Tunis. Tunisia \\ 'Institut des Régions Arides, 4119 Mednine. Tunisia \\ fFaculdade de Ciências de Lisboa, Universidade de Lisboa, DBV, IBB Centro de Biotecnologia Vegetal, \\ C2, Campo Grande, 1749-016 Lisbon. Portugal
}

(Received: 5 January 2009; accepted: 26 May 2009)

\begin{abstract}
The chemical composition, the antioxidant and the antibacterial activities of essential oils, isolated from the aerial parts of Tunisian Thymus capitatus during the flowering phase, and stored in the dark during 37 days in the oven, at $60{ }^{\circ} \mathrm{C}$ were evaluated. Samples taken periodically were used to evaluate the chemical composition, the antioxidant and the antibacterial activities. With some fluctuations, carvacrol (68-74\%) was the major component of the oil independent of the storage period. $\alpha$-Terpinene and $\gamma$-terpinene decreased over time, whereas $p$-cymene increased in the same period. Despite the thirty-seven days of storage at $60{ }^{\circ} \mathrm{C}, T$. capitatus essential oil still showed high antioxidant and stable antimicrobial activity.
\end{abstract}

Keywords: Thymus capitatus, essential oils, thermal stability, biological activities

Plant volatile oils have been recognized since antiquity to possess biological activities. The most important are their antibacterial, antifungal and antioxidant properties (ADAMs et al., 1998; EDRIS, 2007).

Nowadays, there is an increasing interest in biological activities of the essential oils, in particular to prevent the deterioration of the constituents of foodstuffs. In view of this, the concern for determination of the efficacy of natural products, especially during food processing, has increased significantly. In the case of foods, it is necessary to determine the ability of natural antioxidants for food protection against oxidative damage causing rancidity in food products, leading to their deterioration. In spite of some essential oils promoting the inhibition of lipid oxidation, and lipid-containing products, in accelerated oxidation conditions, for example, with increased temperature (e.g. during food processing), the effect of this condition on essential oils composition and activity is rarely discussed. To the best of our knowledge, only TOMAINO and co-workers (2005) studied the effect of heating $\left(80-180^{\circ} \mathrm{C}\right)$ on free radical-scavenger activity and on the chemical composition of some spice essential oils employed in the food industry.

\footnotetext{
* To whom correspondence should be addressed.

Phone: +351289800900; Fax: +351289818419; e-mail: mgmiguel@ualg.pt
} 
In the mean time, apprehension has grown about foodborne microorganisms (ADAMs et al., 1998; Ruberto et al., 2000; FALEIRo et al., 2005). In fact, the consumption of food contaminated with foodborne bacteria, such as meat, fish, vegetables, and dairy products, especially cheese, can constitute a serious health risk to humans. In addition, the importance of this foodborne pathogen is reinforced by the ability to adapt when exposed to sublethal conditions during food processing and gain tolerance to more severe conditions (FRIEDMAN et al., 2002; Singh et al., 2003; FAlEIRO et al., 2005). There is therefore interest for searching new methods of making food safe as well as of using natural products as antibacterial additives.

In Tunisia, the genus Thymus (Lamiaceae) is mainly represented by Thymus capitatus Hoff. et Link. [= Coridothymus capitatus (L.) Rchb. f., Satureja capitata L., Thymbra capitata (L.) Cav.], a perennial, herbaceous shrub commonly used as a spicy herb and locally known under the common name "zaâtar". In view of the antibacterial and antioxidant capacity of this species oils (BOUNATIROU et al., 2007), the purpose of this work was to evaluate its thermal stability when stored for over a month at $60^{\circ} \mathrm{C}$, and to assess the corresponding effect on the chemical composition, antibacterial and antioxidant activities.

\section{Materials and methods}

\subsection{Plant material}

Samples (approximately $30 \mathrm{~g}$ dry weight) of the aerial parts from Thymus capitatus Hoff. et Link., growing wild in Tunisia, were collected during the vegetative (January, 2005), the flowering and the post-flowering phases (July-August, 2005) from three different localities: Jendouba (interior north), Haouaria (littoral north) and Aîn Tounine (littoral south). The plant material was dried in the dark at room temperature before extraction.

\subsection{Essential oil extraction and thermal stability assay}

Essential oil was obtained from each collected material, in a total of 16 samples, by hydrodistillation during $3 \mathrm{~h}$ using a Clevenger-type apparatus (European Pharmacopoeia, 1996). The essential oils were kept at $-4{ }^{\circ} \mathrm{C}$ until analysis. The study of the composition of these oils (BOUNATIROU et al., 2007) indicated strong oil chemical homogeneity and that higher antioxidant and antibacterial activity was observed with the flowering and the post-flowering phase essential oils. In view of this, these oils were combined in order to have enough oil to perform the different thermal stability studies. The oil mixture was kept in closed, transparent $10 \mathrm{ml}$ glass tubes, in an oven at $60{ }^{\circ} \mathrm{C}$ in the dark for 37 days. Aliquots of oil were taken periodically to perform the time course study of oil composition and biological activities.

\subsection{Essential oils analysis}

Gas chromatography: Gas chromatographic analyses were performed using a Perkin Elmer 8700 gas chromatograph equipped with two flame ionization detectors (FIDs), a data handling system and a vapourising injector port into which two columns of different polarities were installed: a DB-1 fused-silica column $(30 \mathrm{~m} \times 0.25 \mathrm{~mm}$ i.d., film thickness $0.25 \mu \mathrm{m}$; J \& W Scientific Inc., Rancho Cordova, CA, USA) and a DB-17HT fused-silica column (30 $\mathrm{m} \times 0.25 \mathrm{~mm}$ i.d., film thickness $0.15 \mu \mathrm{m}$; J \& W Scientific Inc.). Oven temperature was programmed, $45-175{ }^{\circ} \mathrm{C}$, at $3{ }^{\circ} \mathrm{C} \mathrm{min}{ }^{-1}$, subsequently at $15{ }^{\circ} \mathrm{C} \mathrm{min}^{-1}$ up to $300{ }^{\circ} \mathrm{C}$, and then held isothermal for $10 \mathrm{~min}$; injector and detector temperatures were $280{ }^{\circ} \mathrm{C}$ and $290{ }^{\circ} \mathrm{C}$, 
respectively; carrier gas, hydrogen, was adjusted to a linear velocity of $30 \mathrm{~cm} \mathrm{~s}^{-1}$. The samples were injected using split sampling technique at a ratio 1:50. The volume of injection was $0.2 \mu \mathrm{l}$ of a pentane-oil solution. The percentage composition of the oils was computed by the normalisation method from the GC peak areas, calculated as mean values of two injections of each oil without using correction factors.

Gas chromatography-mass spectrometry: The GC-MS unit consisted of a Perkin Elmer Autosystem XL gas chromatograph, equipped with DB-1 fused-silica column $(30 \mathrm{~m} \times 0.25$ mm i.d., film thickness $0.25 \mu \mathrm{m}$; J \& W Scientific, Inc.), and was interfaced with PerkinElmer Turbomass mass spectrometer (software version 4.1). Injector and oven temperatures were as above; transfer line temperature, $280{ }^{\circ} \mathrm{C}$; ion trap temperature, $220{ }^{\circ} \mathrm{C}$; carrier gas, helium, was adjusted to a linear velocity of $30 \mathrm{~cm} \mathrm{~s}^{-1}$; split ratio, 1:40; ionisation energy, $70 \mathrm{eV}$; ionization current, $60 \mu \mathrm{A}$; scan range, 40-300 u; scan time, $1 \mathrm{~s}$. The identity of the components was assigned by comparison of their retention indices relative to $\mathrm{C}_{9}-\mathrm{C}_{16}$ $n$-alkane indices and GC-MS spectra from a home-made library, based on data of components of reference oils (RO), laboratory-synthesised components (LSC) and commercially available standards (CAS) from a home-made library. RO 1. Thymus caespititius oils, RO 2. Cinnamomum zeylanicum oil, RO 3. Achillea milefollium oils. CAS 1. Extrasynthese (Cymit Química, S.L., Barcelona, Spain), CAS 2. Sigma-Aldrich (Steinheim, Germany). CAS 3. Fluka (Steinheim, Germany), CAS 4. Riedel-de Haën (Seelze, Germany).

\subsection{Antioxidant activity}

From each sample, different concentrations of essential oils were prepared in methanol: 100, 500 and $1000 \mathrm{mg} \mathrm{l}^{-1}$. The antioxidant activity of $T$. capitatus essential oils was carried out using two different methods: free radical scavenging activity using DPPH (2,2-diphenyl-1picrylhydrazyl) and by the TBARS (thiobarbituric acid reactive substances) assays.

Free radical scavenging activity: Modified DPPH (2,2-diphenyl-2-picryl-hydrazil) method was used (BLoIs, 1958). Briefly, a solution of DPPH in methanol (24 $\left.\mu \mathrm{g} \mathrm{ml}^{-1}\right)$ was prepared and $2 \mathrm{ml}$ of this solution was added to $50 \mu \mathrm{l}$ of extracts solution in methanol at different concentrations $\left(100,500\right.$ and $\left.1000 \mathrm{mg} \mathrm{l}^{-1}\right)$. Then the absorbance was measured at $517 \mathrm{~nm}$ in a spectrophotometer Shimadzu 160-UV after 5 min (LEBEAU et al., 2000). Radical scavenging activity was calculated using the following equation: Scavenging effect $\%=$ $\left[\left(\mathrm{A}_{0}-\mathrm{A}_{1}\right) / \mathrm{A}_{0}\right] * 100$, where $\mathrm{A}_{0}$ was the absorbance of the control sample (without essential oil) and $A_{1}$ was the absorbance in the presence of the sample $(t=5 \mathrm{~min})$.

TBARS assay: A modified thiobarbituric acid-reactive substances (TBARS) assay (WoNG et al., 1995) was also used to measure the potential antioxidant capacity of T. capitatus essential oils. Egg yolk homogenate was used as lipid-rich media. An aliquot of yolk material was made up to a concentration of $10 \%(\mathrm{w} / \mathrm{v})$ in $\mathrm{KCl}(1.15 \%, \mathrm{w} / \mathrm{v})$. The yolk was then homogenised for $30 \mathrm{~s}$, followed by ultrasonication for further $5 \mathrm{~min}$. Five hundred $\mu \mathrm{l}$ of $10 \%(\mathrm{w} / \mathrm{v})$ homogenate and $100 \mu \mathrm{l}$ of sample, solubilised in methanol, were added to a test tube and made up to $1 \mathrm{ml}$ with distilled water, followed by addition of $1.5 \mathrm{ml}$ of $20 \%$ acetic acid (pH 3.5) and $1.5 \mathrm{ml}$ of $0.8 \%(\mathrm{w} / \mathrm{v})$ 2-thiobarbituric acid (TBA) in $1.1 \%(\mathrm{w} / \mathrm{v})$ sodium dodecyl sulphate (SDS). Each essential oil sample and tested substance was assayed at concentrations of 100, 500 and $1000 \mathrm{mg} \mathrm{l}^{-1}$. This mixture was stirred in a vortex, and heated at $95^{\circ} \mathrm{C}$ for $1 \mathrm{~h}$. After cooling at room temperature, $5 \mathrm{ml}$ butane-1-ol was added to each tube, stirred and centrifuged at 3.000 r.p.m. for $10 \mathrm{~min}$. The absorbance of the supernatant was measured at $532 \mathrm{~nm}$ using a spectrophotometer Shimadzu 160-UV. All values were expressed as antioxidant index (AI\%), calculated by the formula: Antioxidant index $\%=\left[\left(\mathrm{A}_{0}-\mathrm{A}_{1}\right) / \mathrm{A}_{0}\right] * 100$, where $\mathrm{A}_{0}$ being the absorbance value of the fully oxidized control and $\mathrm{A}_{1}$, the absorbance of the test sample. 


\subsection{Antimicrobial activity determination}

The microorganisms used in this study were three different strains of Staphylococus aureus, C15, ATCC6538, ATCC25923, and these trains were a gift from INETI-DTIA (Instituto Nacional de Engenharia e Tecnologia Industrial, Departamento de Tecnologia das Industrias Alimentares). The antimicrobial activity of essential oils was tested by the disc agar diffusion method as described by BurT and ReInDERs (2003) and FALEIRO and co-workers (2003; 2005). Original cultures are kept at $-80^{\circ} \mathrm{C}$. Prior to the assay, the bacterial cultures were plated in fresh agar BHI (Brain Heart Infusion) plates and grown for $24 \mathrm{~h}$ at $37^{\circ} \mathrm{C}$. From each plate a loop was used to inoculate $10 \mathrm{ml}$ of BHI and left for about $2 \mathrm{~h}$ at $37{ }^{\circ} \mathrm{C}$ until the cultures reached the exponential phase. From the above exponential culture $100 \mu \mathrm{l}$ were used to inoculate BHI agar plates. Sterile filter paper discs $(6 \mathrm{~mm}$, Oxoid), containing $4 \mu \mathrm{l}(0.8 \mu \mathrm{l} /$ disc) of essential oil diluted (1:5) in propanol were distributed on the agar surface. Sterile water was used as the negative control, whereas the antibiotic cloramphenicol disc was used as positive control $(30 \mu \mathrm{g} / \mathrm{disc})$. Inhibition zones were determined after an incubation period of $24 \mathrm{~h}$ at $37^{\circ} \mathrm{C}$. The antibiotic was not submitted to the temperature of the assay $\left(60^{\circ} \mathrm{C}\right)$.

\subsection{Statistical analysis}

The obtained antioxidant and antimicrobial results were stated in mean \pm standard deviation. Analysis of variance was performed by ANOVA procedures (SPSS 14.0 for Windows). Significant differences between means were determined by Tukey Post Hoc tests. P values inferior to 0.05 were regarded as significant.

\section{Results and discussion}

\subsection{Essential oil chemical composition}

Thirty-two components were identified in the eight $T$. capitatus essential oil samples analysed after storage at $60{ }^{\circ} \mathrm{C}$, for 37 days in the dark, amounting to $92-100 \%$ of the total oils, which are listed in Table 1 in order of their elution from a DB-1 column. All of the oils analysed were dominated by the monoterpene fraction (95-97\%), the oxygen-containing monoterpene being the most representative group $(71-77 \%)$ of this fraction and in all other oils. Sesquiterpenes ranged from $2-3 \%$ in the oil samples.

Carvacrol was the main component of all the essential oils, independently of the storage period (68-74\%). This component was already reported by other authors as being the major one present in the same plant species collected in Tunisia (HedHILI et al., 2005; Bounatirou et al., 2007). $p$-Cymene and $\gamma$-terpinene were also present in considerable amounts in the beginning of the assay ( $9 \%$ for both). In general, $p$-cymene increased over time, whereas $\gamma$-terpinene decreased. Such profile suggests that heating samples promoted the aromatisation of $\gamma$-terpinene generating $p$-cymene.

The increase in the relative amount of $p$-cymene over time at $60^{\circ} \mathrm{C}$ can be explained by its thermodynamic stability in relation to $\alpha$-thujene, $\alpha$-terpinene, and $\gamma$-terpinene (HARDER $\&$ Foss, 1999). In fact, a decrease of $\alpha$-terpinene (from $2 \%$ in the beginning to zero at the end of the assay) and $\alpha$-thujene (from 1 to $0.1 \%$ ) was also registered (Table 1 ). In the present work, the temperature assayed might be responsible for the isomerisation and aromatisation processes. The aromatisation of $\gamma$-terpinene to $p$-cymene is a normal biosynthetic pathway in plants (Poulouse \& CRoteau, 1978). In essential oils submitted to different temperatures 
(from room temperature to $180{ }^{\circ} \mathrm{C}$, for $3 \mathrm{~h}$ ), Tomaino and co-workers (2005) reported an increase of some components. For oregano and thyme oils, $p$-cymene amounts were higher at $180{ }^{\circ} \mathrm{C}$ then at room temperature, nevertheless without statistical significance.

Table 1. Percentage composition of the essential oils isolated from the aerial parts of T. capitatus, maintained at $60{ }^{\circ} \mathrm{C}$ for 37 days

\begin{tabular}{|c|c|c|c|c|c|c|c|c|}
\hline \multirow{3}{*}{ IP* } & \multirow{3}{*}{ Components } & \multirow{3}{*}{ RI } & \multicolumn{6}{|c|}{ Thymus capitatus } \\
\hline & & & \multicolumn{6}{|c|}{ Time (days) } \\
\hline & & & 0 & 4 & 8 & 11 & 28 & 37 \\
\hline RO 1, RO 2 & $\alpha$-Thujene & 924 & 1.3 & 0.8 & 0.7 & 0.6 & 0.1 & 0.5 \\
\hline CAS 1, RO 1 & $\alpha$-Pinene & 930 & 0.8 & 0.6 & 0.6 & 0.6 & 0.5 & 0.2 \\
\hline CAS 1, RO 1 & Camphene & 938 & 0.3 & 0.2 & 0.2 & 0.2 & 0.2 & 0.1 \\
\hline CAS 2 & 1-Octen-3-ol & 961 & 0.1 & 0.1 & 0.1 & $\mathrm{t}$ & 0.1 & 0.1 \\
\hline CAS 1 , RO 1, RO 2 & $\beta$-Pinene & 963 & 0.1 & 0.1 & 0.1 & $\mathrm{t}$ & 0.2 & 0.1 \\
\hline CAS 2, RO 1, RO 2 & Myrcene & 975 & 2.2 & 1.6 & 1.7 & 1.6 & 1.2 & 1.3 \\
\hline CAS 2, RO 1, RO 2 & $\alpha$-Phellandrene & 995 & 0.3 & 0.3 & 0.2 & 0.3 & 0.1 & $\mathrm{t}$ \\
\hline CAS 2, RO 1, RO 2 & $\delta$-3-Carene & 1000 & 0.1 & 0.1 & 0.1 & 0.1 & 0.1 & $\mathrm{t}$ \\
\hline CAS 2, RO 1, RO 2 & $\alpha$-Terpinene & 1002 & 1.9 & 1.4 & 1.3 & 1.2 & 0.2 & $\mathrm{t}$ \\
\hline CAS 2, RO 1, RO 2 & $p$-Cymene & 1003 & 9.2 & 9.0 & 11.3 & 12.7 & 16.0 & 17.0 \\
\hline CAS 1 , RO 1, RO 2 & $\beta$-Phellandrene & 1005 & 0.3 & 0.3 & 0.3 & 0.3 & 0.2 & 0.2 \\
\hline CAS 3, RO 1, RO 2 & Limonene & 1009 & 0.4 & 0.4 & 0.4 & 0.4 & 0.4 & 0.4 \\
\hline CAS 3, RO 1, RO 2 & cis- $\beta$-Ocimene & 1017 & $\mathrm{t}$ & $\mathrm{t}$ & $\mathrm{t}$ & $\mathrm{t}$ & $\mathrm{t}$ & $\mathrm{t}$ \\
\hline CAS 3, RO 1, RO 2 & trans- $\beta$-Ocimene & 1027 & $\mathrm{t}$ & $\mathrm{t}$ & $\mathrm{t}$ & $\mathrm{t}$ & $\mathrm{t}$ & $\mathrm{t}$ \\
\hline CAS 2, RO 1, RO 2 & $\gamma$-Terpinene & 1035 & 9.2 & 6.5 & 5.2 & 4.3 & 0.2 & 0.3 \\
\hline CAS 3 & trans-Sabinene hydrate & 1037 & 0.1 & 0.2 & 0.2 & 0.1 & $\mathrm{t}$ & $\mathrm{t}$ \\
\hline CAS 2, RO 1, RO 2 & Terpinolene & 1064 & 0.2 & 0.1 & 0.1 & 0.1 & 0.1 & $\mathrm{t}$ \\
\hline CAS 3 & cis-Sabinene hydrate & 1066 & 0.1 & $\mathrm{t}$ & $\mathrm{t}$ & $\mathrm{t}$ & $\mathrm{t}$ & $\mathrm{t}$ \\
\hline CAS 2 & Linalool & 1074 & 0.8 & 0.9 & 0.9 & 0.8 & 1.4 & 1.2 \\
\hline CAS & Borneol & 1134 & 0.4 & 0.5 & 0.5 & 0.5 & 0.6 & 0.6 \\
\hline CAS 2, RO 1, RO 2 & Terpinen-4-ol & 1148 & 0.5 & 0.6 & 0.6 & 0.6 & 1.0 & 0.9 \\
\hline CAS 4, RO 1 & Thymol & 1275 & 0.4 & 0.4 & 0.4 & 0.4 & 0.7 & 0.6 \\
\hline CAS 3, RO 1 & Carvacrol & 1286 & 68.3 & 72.6 & 70.4 & 71.8 & 73.6 & 73.7 \\
\hline CAS 2, RO 3 & Eugenol & 1327 & $\mathrm{t}$ & $\mathrm{t}$ & $\mathrm{t}$ & $\mathrm{t}$ & $\mathrm{t}$ & $\mathrm{t}$ \\
\hline RO 1 & Carvacrol acetate & 1348 & $\mathrm{t}$ & 0.2 & 0.1 & 0.2 & 0.1 & $\mathrm{t}$ \\
\hline CAS 2, RO 1, RO 2 & $\beta$-Caryophyllene & 1414 & 1.6 & 2.0 & 1.8 & 1.8 & 0.6 & 1.3 \\
\hline RO 2 & Aromadendrene & 1428 & 0.2 & 0.1 & 0.2 & 0.1 & 0.5 & $\mathrm{t}$ \\
\hline
\end{tabular}


Table 1. continued

\begin{tabular}{|c|c|c|c|c|c|c|c|c|}
\hline \multirow{3}{*}{$\mathrm{IP} *$} & \multirow{3}{*}{ Components } & \multirow{3}{*}{ RI } & \multicolumn{6}{|c|}{ Thymus capitatus } \\
\hline & & & \multicolumn{6}{|c|}{ Time (days) } \\
\hline & & & 0 & 4 & 8 & 11 & 28 & 37 \\
\hline CAS 3, RO 1, RO 2 & $\alpha$-Humulene & 1447 & 0.1 & $\mathrm{t}$ & $\mathrm{t}$ & $\mathrm{t}$ & $\mathrm{t}$ & $\mathrm{t}$ \\
\hline RO 1 & Viridiflorene & 1487 & $\mathrm{t}$ & $\mathrm{t}$ & $\mathrm{t}$ & $\mathrm{t}$ & $\mathrm{t}$ & $\mathrm{t}$ \\
\hline RO 1, RO 2 & $\beta$-Bisabolene & 1494 & 0.1 & 0.1 & 0.1 & 0.2 & 0.2 & 0.3 \\
\hline RO 1 & Spathulenol & 1551 & $\mathrm{t}$ & $\mathrm{t}$ & $\mathrm{t}$ & $\mathrm{t}$ & $\mathrm{t}$ & $\mathrm{t}$ \\
\hline \multirow[t]{9}{*}{ CAS 3, RO 1, RO 2} & $\beta$-Caryophyllene oxide & 1561 & 0.2 & 0.6 & 0.6 & 0.8 & 1.1 & 0.7 \\
\hline & $\%$ Identification & & 99.2 & 99.4 & 98.0 & 99.6 & 99.3 & 99.7 \\
\hline & Grouped components & & & & & & & \\
\hline & $\begin{array}{l}\text { Monoterpene } \\
\text { hydrocarbons }\end{array}$ & & 26.3 & 21.3 & 22.3 & 22.4 & 19.4 & 20.2 \\
\hline & $\begin{array}{l}\text { Oxygen-containing } \\
\text { monoterpenes }\end{array}$ & & 70.6 & 75.2 & 73.0 & 74.3 & 77.3 & 77.1 \\
\hline & $\begin{array}{l}\text { Sesquiterpene } \\
\text { hydrocarbons }\end{array}$ & & 1.9 & 2.3 & 2.0 & 2.1 & 1.4 & 1.6 \\
\hline & $\begin{array}{l}\text { Oxygen-containing } \\
\text { sesquiterpenes }\end{array}$ & & 0.3 & 0.6 & 0.6 & 0.8 & 1.1 & 0.7 \\
\hline & Phenylpropanoids & & $\mathrm{t}$ & $\mathrm{t}$ & $\mathrm{t}$ & $\mathrm{t}$ & $\mathrm{t}$ & $\mathrm{t}$ \\
\hline & Others & & 0.1 & 0.1 & 0.1 & $\mathrm{t}$ & 0.1 & 0.1 \\
\hline
\end{tabular}

*IP: Identification procedure. All components were identified based on a home-made library created with reference oils (RO), laboratory-synthesized components (LSC) and commercial available standards (CAS). RO 1. Thymus caespititius oils, RO 2. Achillea milefollium oils, RO 3. Cinnamomum zeylanicum oil. CAS 1. Extrasynthese (Cymit Química, S.L.), CAS 2. Sigma-Aldrich, CAS 3. Fluka, CAS 4. Riedel-de Haën.

RI: Retention Index relative to $\mathrm{C}_{9}-\mathrm{C}_{16} n$-alkanes on the DB- 1 column, $\mathrm{t}$ : traces $(<0.05 \%)$

\subsection{Antioxidant activity}

Although differences were detected on the relative amounts of some components of $T$. capitatus oil, maintained at $60{ }^{\circ} \mathrm{C}$ over 37 days, they were not sufficiently important to modifying the ability to prevent lipid peroxidation or the free radical-scavanger effectiveness (Table 2), particularly at the highest concentrations tested (500 and $1000 \mathrm{mg} \mathrm{l}^{-1}$ ).

From the thermal stability point of view, and with the exception of the fourth day of study, heating the essential oil of T. capitatus did not greatly influence its antioxidant ability when evaluated by the TBARS method at the highest concentrations tested (500 and $1000 \mathrm{mg} \mathrm{l}^{-1}$ ) (Table 2). At the lowest concentration $\left(100 \mathrm{mg} \mathrm{l}^{-1}\right)$, the antioxidant activity improved with the time of storage at $60{ }^{\circ} \mathrm{C}$, which remains difficult to explain. Some new compounds formed during storage and detected by GC analysis might be responsible for these results. 
Table 2. Antioxidant index and scavenging effect (\%) of Thymus capitatus essential oils during storage at $60{ }^{\circ} \mathrm{C}$ using TBARS and DPPH scavenging activity assays

\begin{tabular}{|c|c|c|c|c|c|c|}
\hline \multirow{3}{*}{$\begin{array}{l}\text { Time } \\
\text { (days) }\end{array}$} & \multicolumn{6}{|c|}{ Antioxidant index (\%) } \\
\hline & \multicolumn{3}{|c|}{$\begin{array}{c}\text { TBARS assay } \\
\text { Concentrations }\left(\mathrm{mg} \mathrm{l}^{-1}\right)\end{array}$} & \multicolumn{3}{|c|}{$\begin{array}{l}\text { DPPH scavenging activity } \\
\text { Concentrations }\left(\mathrm{mg} \mathrm{l}^{-1}\right)\end{array}$} \\
\hline & 100 & 500 & 1000 & 100 & 500 & 1000 \\
\hline 0 & $17.3 \pm 3.6 \mathrm{a}$ & $90.8 \pm 0.9 \mathrm{~cd}$ & $88.2 \pm 1.4 \mathrm{~b}$ & $11.0 \pm 2.3 \mathrm{a}$ & $69.3 \pm 4.4 \mathrm{a}$ & $90.5 \pm 1.4 \mathrm{a}$ \\
\hline 4 & $53.4 \pm 3.6 \mathrm{~b}$ & $66.5 \pm 0.9 \mathrm{a}$ & $81.8 \pm 1.4 \mathrm{a}$ & $31.9 \pm 2.3 b c$ & $76.9 \pm 4.4 \mathrm{ab}$ & $92.0 \pm 1.4 \mathrm{a}$ \\
\hline 8 & $75.2 \pm 3.6 \mathrm{c}$ & $85.9 \pm 0.9 \mathrm{~b}$ & $89.1 \pm 1.4 b$ & $29.6 \pm 2.3 b$ & $82.8 \pm 4.4 \mathrm{abc}$ & $91.2 \pm 1.4 \mathrm{a}$ \\
\hline 11 & $79.3 \pm 3.6 \mathrm{~cd}$ & $89.1 \pm 0.9 \mathrm{c}$ & $90.2 \pm 1.4 \mathrm{~b}$ & $35.3 \pm 2.3 \mathrm{bc}$ & $82.5 \pm 4.4 \mathrm{abc}$ & $90.4 \pm 1.4 \mathrm{a}$ \\
\hline 28 & $88.6 \pm 3.6 \mathrm{~d}$ & $92.7 \pm 0.9 \mathrm{~d}$ & $93.0 \pm 1.4 \mathrm{~b}$ & $38.8 \pm 2.3 c$ & $92.7 \pm 4.4 \mathrm{c}$ & $93.0 \pm 1.4 \mathrm{a}$ \\
\hline 37 & $89.5 \pm 3.6 \mathrm{~d}$ & $92.5 \pm 0.9 \mathrm{~d}$ & $92.8 \pm 1.4 \mathrm{~b}$ & $38.5 \pm 2.3 \mathrm{c}$ & $92.5 \pm 4.4 \mathrm{c}$ & $92.8 \pm 1.4 \mathrm{a}$ \\
\hline
\end{tabular}

Values represent mean \pm standard deviation of three replicates.

Values followed by the same letter under the same column are not significantly different $(\mathrm{P}>0.05)$

The dominance of carvacrol in T. capitatus oil can be partly responsible for the antioxidant ability detected. The antioxidant activity ability of carvacrol and thymol was already mentioned by many authors (Deighton et al., 1993; Madsen \& Bertelsen, 1995; Baratta et al., 1998; YANishlieva et al., 1999; RUBerto \& BARATTA, 2000). The decrease of $\alpha$-terpinene and $\gamma$-terpinene over time did not decrease the antioxidant capacity of T. capitatus essential oil, in contrast to that reported by RUBERTO and BARATTA (2000) who found a good antioxidant ability of these pure components, even comparable to that of $\alpha$-tocopherol. The fact that $T$. capitatus oil is a complex mixture makes it difficult to establish a correlation between its antioxidant activity and each of the oil components.

When DPPH radical scavenging activity of T. capitatus oil stored at $60{ }^{\circ} \mathrm{C}$ for 37 days was evaluated, all the samples showed comparable scavenging activity, particularly for the concentrations of 500 and $1000 \mathrm{mg} \mathrm{l}^{-1}$ (Table 2). The free radical-scavenger effectiveness of the oil at $100 \mathrm{mg} \mathrm{l}^{-1}$ was not as high as the antioxidant indices measured by the TBARS method, mainly at the end of the assay. As it was found for the TBARS method, the radical scavenging activity of the oil was not much influenced by the time of storage at $60{ }^{\circ} \mathrm{C}$.

TOMAINo and co-workers (2005) using similar concentrations $\left(0.026-1.32 \mu \mathrm{ml}^{-1}\right)$ of diverse essential oils to those assayed in our work in order to investigate the influence of thermal treatment on their free radical-scavenger activity found that temperature did not greatly influence antioxidant activity of the oils.

\subsection{Antimicrobial activity}

Data on antibacterial activity of the essential oil maintained at $60{ }^{\circ} \mathrm{C}$ for 37 days indicate stability of essential oil properties (Table 3). The tested Staphylococcus aureus strains demonstrated a significantly different $(\mathrm{P}<0.05)$ susceptibility to the essential oil during the assay period. The most susceptible strain was ATCC 6538 and no significant differences $(\mathrm{P}>0.05)$ between the susceptibilities of strains C15 and ATCC 25923 was found (Table 3). 
Table 3. Susceptibility of Staphylococus aureus strains (ATCC 6538, C15 and ATCC 25923)

to essential oil mixture maintained at $60^{\circ} \mathrm{C}$ during 37 days, expressed by diameter of inhibition zone (including the disc diameter, $6 \mathrm{~mm}$ ) at concentration $0.8 \mu \mathrm{l} / \mathrm{disc}$

\begin{tabular}{lccc}
\hline \multirow{2}{*}{ Time (days) } & \multicolumn{3}{c}{ Staphylococus aureus } \\
\cline { 2 - 3 } & ATCC 6538 & C15 & ATCC 25923 \\
\hline 0 & $41.3 \pm 1.2 \mathrm{a}$ & $13.0 \pm 1.0 \mathrm{a}$ & $12.7 \pm 1.2 \mathrm{a}$ \\
4 & $40.7 \pm 1.2 \mathrm{a}$ & $13.7 \pm 0.6 \mathrm{a}$ & $13.7 \pm 1.2 \mathrm{a}$ \\
8 & $40.7 \pm 0.6 \mathrm{a}$ & $15.7 \pm 0.6 \mathrm{a}$ & $12.0 \pm 0.0 \mathrm{a}$ \\
11 & $42.0 \pm 1.7 \mathrm{a}$ & $15.7 \pm 2.1 \mathrm{a}$ & $12.3 \pm 0.6 \mathrm{a}$ \\
16 & $41.0 \pm 2.0 \mathrm{a}$ & $13.0 \pm 1.0 \mathrm{a}$ & $12.0 \pm 1.0 \mathrm{a}$ \\
23 & $42.3 \pm 2.5 \mathrm{a}$ & $14.0 \pm 1.7 \mathrm{a}$ & $12.3 \pm 0.6 \mathrm{a}$ \\
28 & $41.0 \pm 3.5 \mathrm{a}$ & $12.0 \pm 0.0 \mathrm{a}$ & $12.7 \pm 0.6 \mathrm{a}$ \\
37 & $40.0 \pm 2.0 \mathrm{a}$ & $12.7 \pm 1.7 \mathrm{a}$ & $11.7 \pm 1.5 \mathrm{a}$ \\
& & & $27.0 \pm 1.0 \mathrm{a}$ \\
\hline
\end{tabular}

Values represent mean \pm standard deviation of three replicates.

Values of the samples followed by the same letter under the same column are not significantly different $(\mathrm{P}>0.05)$. Values of the antibiotic susceptibility are the mean of the determinations along the assay. Data followed by the same letter under the same row are not significantly different $(\mathrm{P}>0.05)$.

The three strains were equally $(\mathrm{P}>0.05)$ susceptible to the antibiotic chloramphenicol (Table 3).

\section{Conclusion}

Deterioration of foodstuffs by oxidation during storage, processing, or heat treatment is a great concern of food industry. Generally, antioxidants added to food are a way to prevent fat oxidation. For its application in foodstuffs, it is necessary to be sure of the chemical and biological stability over time. In the present case, thermal stability of the essential oils isolated from $T$. capitatus of Tunisia was evaluated.

The present results indicate the possible use of T. capitatus essential oil in food industry, since it does not lose either antioxidant or antibacterial ability, even when stored at relative high temperature $\left(60^{\circ} \mathrm{C}\right)$ for a period higher than a month (37 days). However, since some quantitative changes occur in the essential oil composition, the extent of these changes in the organoleptic properties of the oil and agreeability to the consumers should be evaluated.

\section{References}

Adams, K., Sivropoulou, A., Kokkini, S., Lanaras, T. \& Arsenakis, M. (1998): Antifungal activities of Origanum vulgare subsp. hirtum, Mentha spicata, Lavandula angustifolia, and Salvia fruticosa essential oils against human pathogenic fungi. J. agric. Fd Chem., 46, 1739-1745.

Baratta, M.T., Dorman, H.J.D., Deans, S.G., Biondi, D.M. \& Ruberto, G. (1998): Chemical composition, antimicrobial and antioxidative activity of laurel, sage, rosemary, oregano and coriander essential oils. J. essent. Oil Res., 10, 618-627. 
Blois, M.S. (1958): Antioxidant determinations by the use of a stable free radical. Nature, 181, 1199-1200.

Bounatirou, S., Smiti, S., Miguel, M.G., Faleiro, L., Rejeb, M.N., Neffati, M., Costa, M.M., Figueiredo, A.C., Barroso, J.G. \& Pedro, L.G. (2007): Chemical composition, antioxidant and antibacterial activities of the essential oils isolated from Tunisian Thymus capitatus Hoff. et Link. Fd Chem., 105, 146-155.

Burt, S.A. \& ReInDERs, R.D. (2003): Antibacterial activity of selected plant essential oils against Escherichia coli O157:H7. Lett. appl. Microbiol., 36, 162-167.

Deighton, N., Glidewell, S.M., Deans, S.G. \& Goodman, B.A. (1993): Identification by EPR spectroscopy of carvacrol and thymol as the major source of free radicals in the oxidation of plant essential oils. $J$. Sci. Fd Agric., 63, 221-225.

EDRIS, A.E. (2007): Pharmaceutical and therapeutic potentials of essential oils and their individual volatile constituents: a review. Phytother. Res., 21, 308-332.

European Pharmacopoeia, (1996): $3^{\text {rd }}$ ed. Council of Europe, Strasbourg, pp. 121-122.

Faleiro, M.L., Miguel, M.G., Ladeiro, F., Venâncio, F., Tavares, R., Brito, J.C., Figueiredo, A.C., Barroso, J.G. \& Pedro, L.G. (2003): Antimicrobial activity of essential oils isolated from Portuguese endemic species of Thymus. Lett. appl. Microbiol., 36, 35-40.

Faleiro, L., Miguel, G., Gomes, S., Costa, L., Venâncio, F., Teixeira, A., Figueiredo, A.C., Barroso, J.G. \& Pedro, L.G. (2005): Antibacterial and antioxidant activities of essential oils isolated from Thymbra capitata L. (Cav.) and Origanum vulgare L. J. agric. Fd Chem., 53, 8162-8168.

Friedman, M., Henika, P.R. \& Mandrell, R.E. (2002): Bactericidal activities of plant essential oils and some of their isolated constituents against Campylobacter jejuni, Escherichia coli, Listeria monocytogenes, and Salmonella enterica. J. Fd Protect., 165, 1545-1560.

HARDER, J. \& Foss, S. (1999): Anaerobic formation of the aromatic hydrocarbon $p$-cymene from monoterpenes by methanogenic enrichment cultures. Geomicrobiol. J., 16, 295-305.

Hedhili, L., Romdhane, M., Planche, H. \& Abderrabba, M. (2005): Towards gas chromatography-mass spectrometry coupling protocols for both identifying and quantification essential oils of Thymus capitatus Hoff et Link. J. Chromatogr. A, 1064, 129-134.

Lebeau, J., Furman, C., Bernier, J.L., Duriez, P., Teissier, E. \& Cotelle, N. (2000): Antioxidant properties of ditert-butylhydroxylated flavonoids. Free Radical Biol. Med., 29, 900-912.

Madsen, H.L. \& Bertelsen, G. (1995): Spices as antioxidants. Trends Fd Sci. Technol., 6, 271-277.

Poulouse, A.J. \& Croteau, R. (1978): Biosynthesis of aromatic monoterpenes: conversion of $\gamma$-terpinene to p-cymene and thymol in Thymus vulgaris L. Arch. Biochem. Biophys., 187, 307-314.

Ruberto, G. \& Baratta, M.T. (2000): Antioxidant activity of selected essential oil components in two lipid model systems. Fd Chem., 69, 167-174.

Ruberto, G., Baratta, M.T., Deans, S.G. \& Dorman, H.J.D. (2000): Antioxidant and antimicrobial activity of Foeniculum vulgare and Crithmum maritimum essential oils. Planta Med., 66, 687-693.

Singh, A., Singh, R.K., Bhunia, A.K. \& Singh, N. (2003): Efficacy of plant essential oils as antimicrobial agents against Listeria monocytogenes in hotdogs. Lebensm. Wiss. Technol., 36, 787-794.

Tomaino, A., Cimino, F., Zimbalatti, V., Venuti, V., Sulfaro, V., De Pasquale, A. \& Saija, A. (2005): Influence of heating on antioxidant activity and the chemical composition of some spice essential oils. Fd Chem., 89, $549-554$.

Wong, J.W., Наsнimoто, K. \& Sнiвамото, T. (1995): Antioxidant activities of rosemary and sage extracts and vitamin $\mathrm{E}$ in a model meat system. J. agric. Fd Chem., 43, 2707-2712.

Yanishlieva, N.V., Marinova, E.M., Gordon, M.H. \& Radeva, V.G. (1999): Antioxidant activity and mechanism of action of thymol and carvacrol in two lipid systems. Fd Chem., 64, 59-66. 